\title{
Effect of Hot Environment on Strength and Heat Transfer Coefficient of Nano-Clay Concrete Paper Title
}

\author{
Wei-Chien Wang, Shao-Yu Wang, Cheng-Hsun Lin \\ Department of Civil Engineering, Chung Yuan Christian University, Taiwan \\ Email: a654.joy@gmail.com
}

Received 30 March 2016; accepted 21 July 2016; published 25 July 2016

\begin{abstract}
This study selected water-cement ratio 0.5 and slump $16 \mathrm{~cm}$ for ACI mix design, and used nanoclay to replace $0.1 \%, 0.3 \%$ and $0.5 \%$ of cement by weight to make cylinder and angle column specimens. The effects of different high temperatures on the compressive strength and heat transfer coefficient were tested, and the ignition loss of nano-clay cement paste was measured. The results showed that an appropriate replacement of nano-clay for $0.3 \%-0.5 \%$ of cement can enhance the strength and heat transfer coefficient of concrete, especially $0.3 \%$ replacement. The $0.1 \%$ nanoclay replacement for cement reduces the strength and heat transfer coefficient of concrete. When the ambient temperature exceeds $300^{\circ} \mathrm{C}$, the nano-clay concrete strength begins to decline, and the heat transfer coefficient decreases greatly, the effect of hot environment on the strength trend of nano-clay concrete is similar to that on normal concrete. When the nano-clay replaces cement by $0 \%-0.5 \%$, the ignition loss is approximately in exponential and logarithmic relationships to the compressive strength respectively when the ignition loss is smaller than and greater than $6 \%$.
\end{abstract}

\section{Keywords}

Nano-Clay, Cement Paste, Concrete, Ignition Loss

\section{Introduction}

When the dimensions of materials enter into the nano range, conventional theories of material science no longer hold true. Nano materials have special characteristics, including the surface effect, small-size effect, quantum size effect, macroscopic quantum tunneling effect, and others [1] [2]. Clay can be divided into two broad categories: natural clay and synthetic clay [3].

Cement paste's main source of strength comes from C-S-H gel and CH crystals, which interact with each other chemically when heated. Its properties after being subjected to heat are affected mainly by the change of water content as well as the decomposition and fusion of minerals. Typically, capillary water and gel pore water evaporate when the temperature reaches $105^{\circ} \mathrm{C}$; at $200^{\circ} \mathrm{C}$, the bonded water inside the C-S-H gel starts to sepa-

How to cite this paper: Wang, W.-C., Wang, S.-Y. and Lin, C.-H. (2016) Effect of Hot Environment on Strength and Heat Transfer Coefficient of Nano-Clay Concrete Paper Title. Journal of Materials Science and Chemical Engineering, 4, 45-52. http://dx.doi.org/10.4236/msce.2016.47007 
rate; at $250^{\circ} \mathrm{C}-300^{\circ} \mathrm{C}$, most of the hydrate bonded water containing $\mathrm{Al}_{2} \mathrm{O}_{3}$ and $\mathrm{Fe}_{2} \mathrm{O}_{3}$ and about $20 \%$ of the bonded water in the C-S-H gel are lost; at $400^{\circ} \mathrm{C}-700^{\circ} \mathrm{C}$, the remaining $80 \%$ of the bonded water in the $\mathrm{C}-\mathrm{S}-\mathrm{H}$ gel breaks down completely; between $500^{\circ} \mathrm{C}-580^{\circ} \mathrm{C}, \mathrm{Ca}(\mathrm{OH})_{2}$ starts to disintegrate; at $750^{\circ} \mathrm{C}$, calcium carbonate starts to disintegrate, releasing $\mathrm{CO}_{2}$, and producing $\mathrm{CaO}$, which swells when it comes into contact with water and causes the concrete to crack [4].

This study simulates the concrete under the effect of fire to research the effect of nano-clay on the compressive strength and heat transfer coefficient of concrete. In addition, the feasibility of using the ignition loss test result to evaluate the retained strength of concrete is analyzed.

\section{Test Planning}

\subsection{Materials and Mix Proportions}

This study conducted ACI mix design using a 0.5 water-cement ratio and a slump of $16 \mathrm{~cm}$ and created specimens with $0 \%, 1 \%, 3 \%$, and $5 \%$ weight of cement replaced by nano-clay (numbered as W5N0, W5N1, W5N3, and W5N5, respectively). The mix proportions are shown in Table 1. Materials used included Type I Portland cement; coarse aggregate with maximum particle diameter of 3/4", 2.54 specific gravity with saturated surface dry, a $1.25 \%$ water absorption capacity, and $1475.4 \mathrm{~kg} / \mathrm{m}^{3}$ dry-rodded unit weight; fine aggregate with a fineness modulus of 2.75, 2.53 specific gravity with saturated surface dry, and a $2.15 \%$ water absorption capacity. The nano-clay used in the tests was light yellow in color with purity greater than $95 \%$ and primarily consisted of $\mathrm{SiO}_{2}, \mathrm{Al}_{2} \mathrm{O}_{3}, \mathrm{Fe}_{2} \mathrm{O}_{3}, \mathrm{MgO}, \mathrm{Na}_{2} \mathrm{O}$, and $\mathrm{TiO}_{2}$, with an average particle diameter smaller than $10 \mu \mathrm{m}$, $\mathrm{pH}$ value between 8 - 9, Portland suction amount of $142.5 \mathrm{mmol} / 100 \mathrm{~g}$, cation exchange capacity equal to 98 , and moisture content less than $3.5 \%$.

\subsection{Test Items and Specimen Production}

There are three test items:

1) Compressive strength of concrete at different curing ages

A $\psi 10 \times 20 \mathrm{~cm}$ cylinder specimen is made according to the mix proportion, stripped on the following day and cured in saturated limewater. The compressive strength on Days 7, 14, 28, 49, 56 and 90 is measured respectively.

2) Compressive strength of concrete in hot environment

A $\psi 10 \times 20 \mathrm{~cm}$ cylinder specimen is made according to mix proportion, stripped on the following day and cured in saturated limewater for 28 days for simulation test for the effect of different high temperatures on the compressive strength. The specimen is taken out of the water and put in $105^{\circ} \mathrm{C}$ oven for 3 days, and then put in high temperature furnace, the specimen is exposed to $25^{\circ} \mathrm{C}, 300^{\circ} \mathrm{C}, 440^{\circ} \mathrm{C}, 500^{\circ} \mathrm{C}, 580^{\circ} \mathrm{C}, 800^{\circ} \mathrm{C}$ and $1000^{\circ} \mathrm{C}$ respectively. It is indicated in literature that the compressive strength of concrete decreases mainly in one-hour delay under the effect of high temperature [5]. Therefore, there is a delay of one hour after the temperature reaches the preset temperature, the compression test is implemented when it is cooled to room temperature. All data are mean values of test results in triplicate.

The cement paste is extracted from the damaged specimen (including a small amount of fine aggregate in small particle size which cannot be removed) to test the ignition loss. The ignition loss test procedure is: 1) take $10 \mathrm{~g}$ sample, weighed $\mathrm{W}_{25} ; 2$ ) put in $105^{\circ} \mathrm{C}$ oven for 24 hours, weighed $\mathrm{W}_{105}$ after cooling; 3) put in full

Table 1. Mix design.

\begin{tabular}{|c|c|c|c|c|}
\hline Number & W5N0 & W5N1 & W5N3 & W5N5 \\
\hline Coarse aggregate & 926.0 & 926.0 & 926.0 & 926.0 \\
\hline Fine aggregate & 758.1 & 758.1 & 758.1 & 758.1 \\
\hline Cement & 410.0 & 409.6 & 408.8 & 408.0 \\
\hline Water & 205.0 & 205.0 & 205.0 & 205.0 \\
\hline Nano-clay & 0.00 & 0.41 & 1.23 & 2.05 \\
\hline
\end{tabular}


electronic high temperature furnace, heated to $440^{\circ} \mathrm{C}$ and delayed 8 hours, weighed $\mathrm{W}_{440}$ after cooling; 4) heated in full electronic high temperature furnace to $580^{\circ} \mathrm{C}$ and delayed 8 hours, weighed $\mathrm{W}_{580}$ after cooling; 5) heated in full electronic high temperature furnace to $1007^{\circ} \mathrm{C}$ and delayed 8 hours, weighed $\mathrm{W}_{1007}$ after cooling; 6) calculate ignition loss (IL), expressed as Equation (1).

$$
I L=\left(W_{105}-W_{1007}\right) /\left(W_{105}-\left(W_{105}-W 1007\right)\right) \times 100 \%
$$

3) Thermal conductivity of concrete in hot environment

A $15 \times 15 \times 24 \mathrm{~cm}$ square angle column specimen is made according to mix proportion, stripped on the following day and cured in saturated limewater for 28 days. This test only considers the longitudinal transfer of heat in concrete. Two $15 \times 15 \mathrm{~cm}$ surfaces are heating surface and radiating surface, wrapped in refractory wool with good heat insulation to avoid the heat energy in the concrete dissipating from sides. The temperature is increased to $800^{\circ} \mathrm{C}$ at heating rate of $5^{\circ} \mathrm{C} / \mathrm{min}$. The temperature data acquisition unit records the temperature change per second. The heat transfer coefficient is calculated by Equation (2).

$$
k=-Q /(A(d T / d x))
$$

where $k=$ heat transfer coefficient $\left(\mathrm{W} / \mathrm{m}-{ }^{\circ} \mathrm{K}\right) ; \mathrm{Q}=$ heat-flow rate $(\mathrm{W}) ; A=$ cross-section area normal to direction of heat flow $\left(\mathrm{m}^{2}\right) ; d T / d x=$ temperature gradient of direction of heat flow $\left({ }^{\circ} \mathrm{K} / \mathrm{m}\right)$.

\section{Results and Discussion}

\subsection{Effect of Small Replacement of Nano-Clay for Cement on Concrete Strength}

The test results are shown in Table 2 and Figure 1. For normal concrete (W5N0), the concrete strength increases with the curing age, the compressive strength on Day 28 is $33.7 \mathrm{MPa}$, the strength on Days 7 and 14 is $73.6 \%$

\begin{tabular}{|c|c|c|c|c|c|}
\hline Curing time (days) & Number & W5N0 & W5N1 & W5N3 & W5N5 \\
\hline 7 & & 24.8 & 21.0 & 27.4 & 25.8 \\
\hline 14 & & 28.1 & 25.6 & 31.7 & 30.4 \\
\hline 28 & & 33.7 & 30.0 & 35.7 & 34.8 \\
\hline 49 & & 36.4 & 32.4 & 38.1 & 36.9 \\
\hline 56 & & 36.8 & 32.8 & 38.4 & 37.3 \\
\hline 90 & & 37.9 & 35.0 & 40.0 & 38.8 \\
\hline
\end{tabular}

Table 2. Compressive strength of concrete at different curing ages.

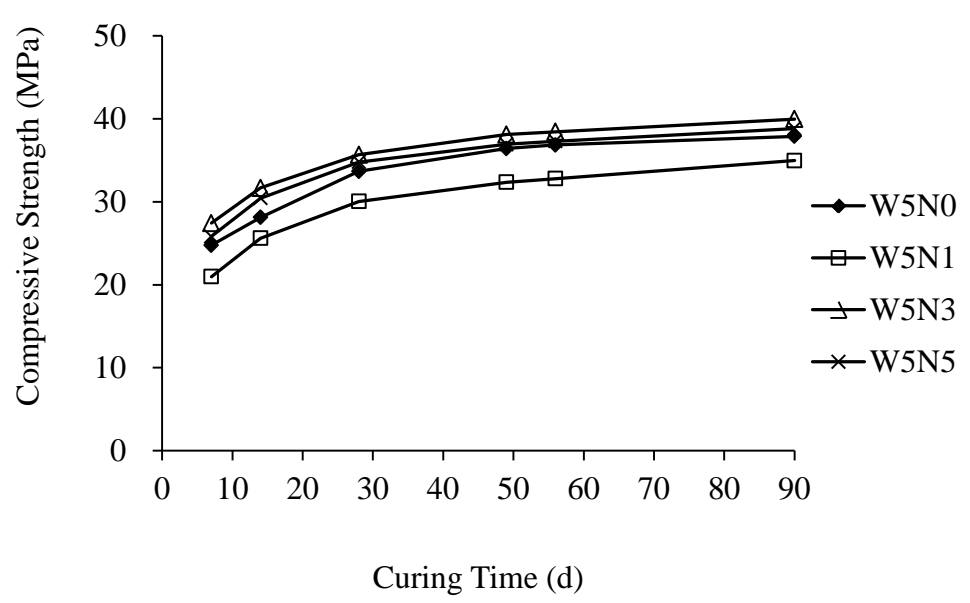

Figure 1. Compressive strength of concrete at different curing ages. 
and $83.4 \%$ of the strength on Day 28 respectively. The compressive strength on Days 56 and 90 is increased by 9.2 and $12.5 \%$ respectively, meaning the strength grows rapidly during the first 28 days of curing, the strength develops slowly after 28 days. The concrete with a small replacement of nano-clay for cement (W5N1, W5N3 and W5N5) has a strength development trend similar to normal concrete, meaning a small amount of nano-clay has no significant impact on the time varying development trend of concrete strength.

Take the curing age of 28 days as an example, $0.1 \%, 0.3 \%$ and $0.5 \%$ nano-clay replace cement by weight, the strength is reduced by $11.0 \%$ and increased by $5.9 \%$ and $3.3 \%$ respectively. The strength of specimens at other ages has similar trends, meaning a proper amount of nano-clay replacing cement by $0.3 \%-0.5 \%$ can increase the concrete strength, and the $0.3 \%$ replacement increases the concrete strength significantly, the $0.1 \%$ nanoclay replacement for cement reduces the concrete strength.

\subsection{Effect of Hot Environment on Concrete Strength}

The test results are shown in Table 3 and Figure 2. For normal concrete (W5N0), there is a delay of one hour at $25^{\circ} \mathrm{C}$ and $300^{\circ} \mathrm{C}$, the strength is increased by $13.4 \%$ and $9.5 \%$ respectively compared with the strength on curing Day 28. This result matches the result of Ref. [6] that the residual strength of concrete is not reduced apparently from normal temperature to $300^{\circ} \mathrm{C}$. However, when one hour delayed in $440^{\circ} \mathrm{C}, 500^{\circ} \mathrm{C}, 580^{\circ} \mathrm{C}, 800^{\circ} \mathrm{C}$ and $1000^{\circ} \mathrm{C}$ environment, the strength is reduced by $14.2 \%, 26.7 \%, 46.9 \%, 76.3 \%$ and $93.8 \%$ respectively compared with the strength on curing Day 28. This result matches the result of Ref. [6] that $400^{\circ} \mathrm{C}-600^{\circ} \mathrm{C}$ is the main strength reduction interval, the residual strength of concrete is mostly lower than $30 \%$ of the original strength when the temperature is higher than $700^{\circ} \mathrm{C}$.

Figure 2 shows that the effect of hot environment on the strength trend of nano-clay concrete is similar to that on normal concrete. In different hot environments, the $0.1 \%$ nano-clay replacement for cement can reduce the concrete strength, the $0.3 \%-0.5 \%$ replacement for cement can increase the concrete strength, and the $0.3 \%$ replacement increases the concrete strength significantly.

Table 3. Compressive strength of concrete in different hot environments.

\begin{tabular}{|c|c|c|c|c|}
\hline Temperature $\left({ }^{\circ} \mathrm{C}\right)$ & W5N0 & W5N1 & W5N3 & W5N5 \\
\hline 25 & 38.2 & 37.5 & 41.6 & 41.1 \\
\hline 300 & 36.9 & 35.9 & 41.1 & 40.3 \\
\hline 440 & 28.9 & 26.3 & 32.9 & 31.4 \\
\hline 500 & 24.7 & 18.5 & 27.3 & 26.0 \\
\hline 580 & 17.9 & 14.5 & 21.1 & 20.4 \\
\hline 800 & 8.0 & 6.0 & 8.8 & 8.6 \\
\hline 1000 & 2.1 & 2.1 & 2.8 & 2.6 \\
\hline
\end{tabular}

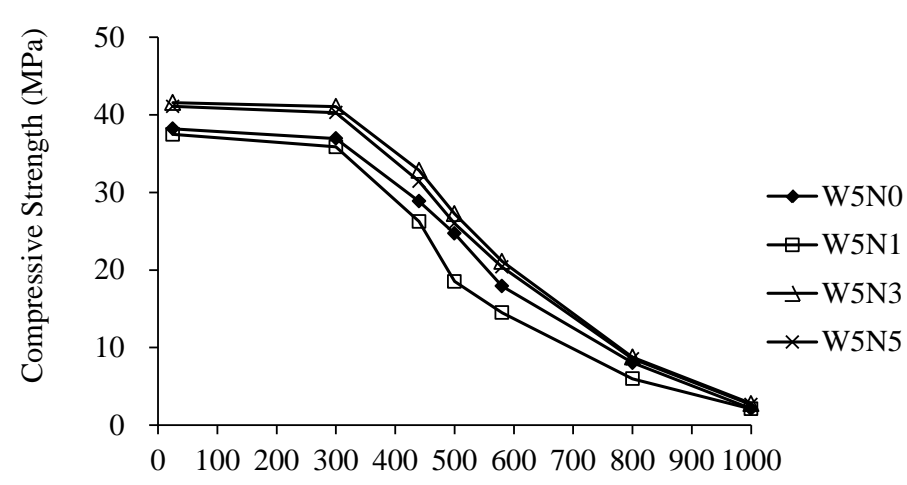

Temperature $\left({ }^{\circ} \mathrm{C}\right)$

Figure 2. Compressive strength of concrete in different hot environments. 


\subsection{Effect of Hot Environment on Thermal Conductivity of Concrete}

Table 4 shows that the heat transfer coefficient of concrete decreases as the ambient temperature rises, matching the findings of Ref. [7]. Figure 3 shows that the maximum decreasing amplitude occurs at $200^{\circ} \mathrm{C}-300^{\circ} \mathrm{C}$, and then the decreasing amplitude decreases as the temperature increases. When the temperature exceeds $100^{\circ} \mathrm{C}$, the pore water in the concrete evaporates gradually, the heat transfer is slowed down. When the temperature is higher than $300^{\circ} \mathrm{C}$, the thermal strain difference between the aggregate and hardened cement paste results in microcracks, increasing the heat transfer paths, and the C-S-H colloid is decomposed gradually, the thermal conduction capability is reduced as a part of aggregate is damaged, so that the heat transfer coefficient decreases faster. When the temperature is higher than $600^{\circ} \mathrm{C}$, the heat is transferred between pores mainly by radiation [8]. The $0.1 \%$ nano-clay replacement for cement can reduce the heat transfer coefficient of concrete, and the $0.3 \%$ and $0.5 \%$ nano-clay replacement can increase the heat transfer coefficient of concrete.

Figure 4 shows the relationship between heat transfer coefficient and compressive strength. It is observed that the heat transfer coefficient decreases with the compressive strength. The decrease of the compressive strength in Figure 4 is resulted from high temperature. Therefore, hot environment reduces the compressive strength and heat transfer coefficient of concrete. According to Table 2 and Table 3, based on the compressive strength of concrete on the curing Day 28, when the ambient temperature is $800^{\circ} \mathrm{C}$, the compressive strength of W5N0, W5N1, W5N3 and W5N5 concrete is reduced by $76.1 \%, 80.1 \%, 75.4 \%$ and $75.4 \%$ respectively. According to Table 4, based on the heat transfer coefficient of concrete at ambient temperature of $200^{\circ} \mathrm{C}$, when the ambient temperature is $800^{\circ} \mathrm{C}$, the heat transfer coefficient of W5N0, W5N1, W5N3 and W5N5 concrete is reduced by $64.4 \%, 63.6 \%, 61.8 \%$ and $62.3 \%$ respectively.

Table 4. Heat transfer coefficient of nano-clay concrete in hot environment.

\begin{tabular}{|c|c|c|c|c|c|}
\hline Temperature $\left({ }^{\circ} \mathrm{C}\right)$ & Number & W5N0 & W5N1 & W5N3 & W5N5 \\
\hline 200 & & 2.05 & 1.95 & 2.17 & 2.12 \\
\hline 300 & & 1.52 & 1.45 & 1.65 & 1.57 \\
\hline 400 & & 1.22 & 1.18 & 1.34 & 1.26 \\
\hline 500 & & 1.04 & 1.00 & 1.16 & 1.07 \\
\hline 600 & & 0.90 & 0.88 & 1.01 & 0.96 \\
\hline 700 & & 0.81 & 0.79 & 0.91 & 0.87 \\
\hline 800 & & 0.73 & 0.71 & 0.83 & 0.80 \\
\hline
\end{tabular}

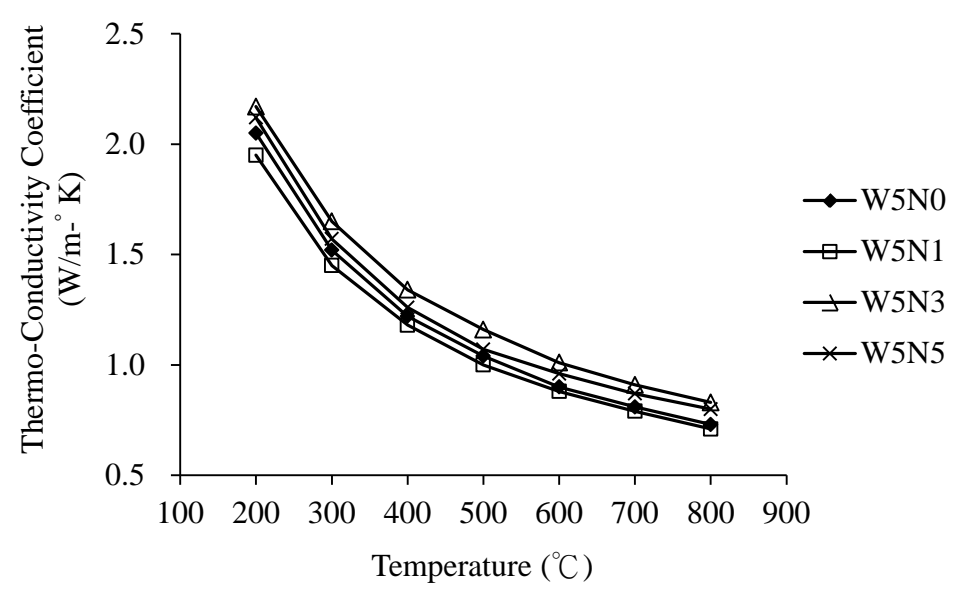

Figure 3. Heat transfer coefficient of nano-clay concrete in hot environment. 


\subsection{Effect of Hot Environment on Ignition Loss of Nano-Clay Cement Paste}

The test results are shown in Table 5 and Figure 5. For normal concrete (W5N0), when the temperature is $300^{\circ} \mathrm{C}$ to $580^{\circ} \mathrm{C}$, the mortar ignition loss decreasing amplitude is increased markedly. Because when the temperature is $300^{\circ} \mathrm{C}-500^{\circ} \mathrm{C}$, most of bonding water of C-S-H colloid has been lost, and $\mathrm{Ca}(\mathrm{OH})_{2}$ begins to be decomposed at $500^{\circ} \mathrm{C}-580^{\circ} \mathrm{C}$ [4]. The $0.1 \%$ - 0.5\% nano-clay replacement for cement has no significant impact on the paste ignition loss trend at high temperature.

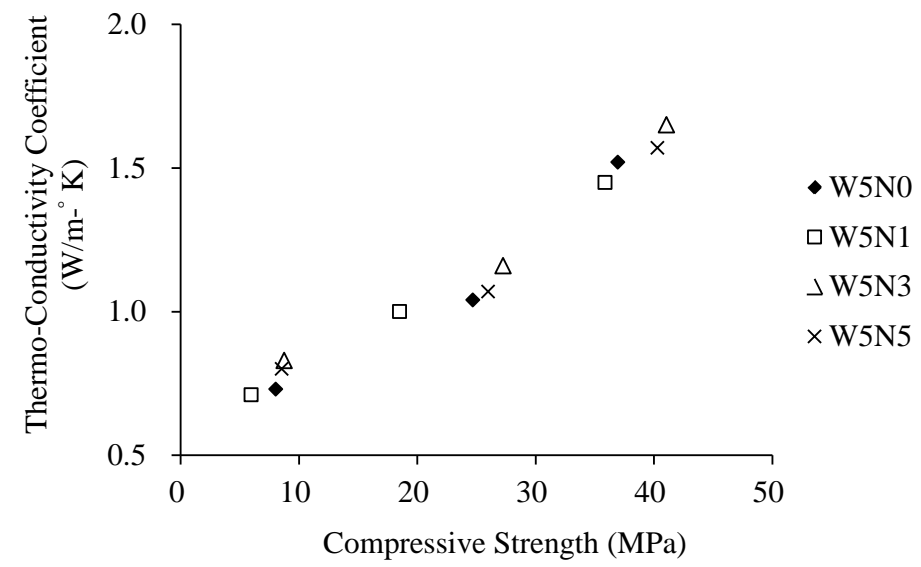

Figure 4. Relationship between heat transfer coefficient and compressive strength.

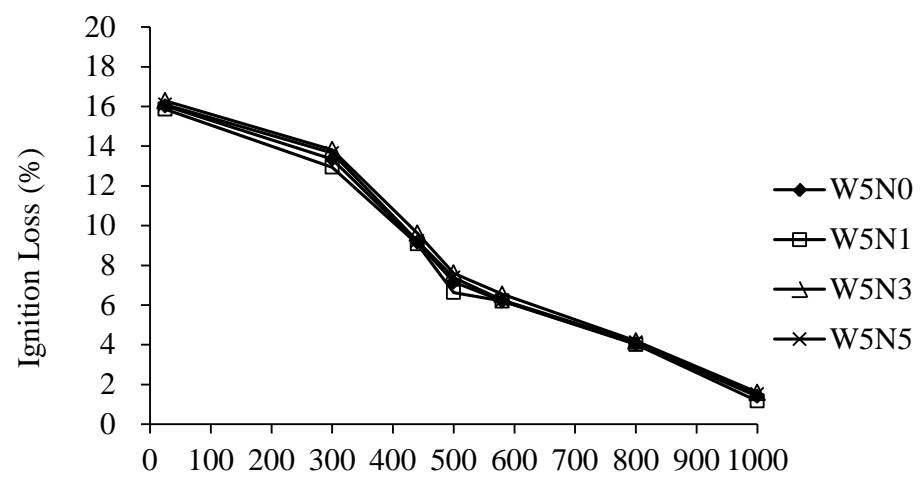

Temperature $\left({ }^{\circ} \mathrm{C}\right)$

Figure 5. Nano-clay cement paste ignition losses in different hot environments.

Table 5. Nano-clay cement paste ignition losses in different hot environments.

\begin{tabular}{cccccc} 
Unit: \% & Number & N0 & N1 & N3 & N5 \\
\hline Temperature $\left({ }^{\circ} \mathrm{C}\right)$ & & 16.0 & 15.9 & 16.3 & 16.1 \\
\hline 25 & 13.3 & 12.9 & 13.8 & 13.7 \\
& 300 & 9.2 & 9.1 & 9.6 & 9.2 \\
500 & 7.2 & 6.6 & 7.6 & 7.4 \\
580 & 6.2 & 6.2 & 6.5 & 6.2 \\
800 & 4.1 & 4.0 & 4.2 & 4.1 \\
1000 & 1.4 & 1.2 & 1.6 & 1.5 \\
\hline
\end{tabular}




\subsection{Relationship between Paste Ignition Loss and Compressive Strength}

Figure 6 shows that the compressive strength increases with ignition loss. Because the ignition loss of paste reflects the degree of cement hydration, and the hot environment results in chemical reaction of cement hydration product. When the temperature is $200^{\circ} \mathrm{C}$, the bonding water begins to deviate from $\mathrm{C}-\mathrm{S}$-H colloid. The paste has lost most water when the temperature is $500^{\circ} \mathrm{C}$, and $\mathrm{Ca}(\mathrm{OH})_{2}$ begins to be decomposed when the temperature is $500^{\circ} \mathrm{C}-580^{\circ} \mathrm{C}$, so that the ignition loss of paste is reduced, namely, the degree of cement hydration is reduced, the higher the ignition loss is, the higher is the degree of cement hydration.

When the water-cement ratio of paste is 0.5 , and the nano-clay replacement for cement is $0 \%-0.5 \%$, the ignition loss is approximately in exponential relationship to the compressive strength when the ignition loss is lower than $6 \%, y=1.267 \mathrm{e}^{0.443 \mathrm{IL}}$, the correlation factor $\left(\mathrm{R}^{2}\right)$ is 0.969 ; when the ignition loss is higher than $6 \%$, the ignition loss is approximately in logarithmic relationship to the compressive strength, $y=22.832 \ln (\mathrm{IL})-22.003$, the correlation factor is 0.920 . Therefore, the compressive strength of concrete can be calculated by ignition loss, or the ambient temperature of concrete can be calculated by ignition loss (Figure 5).

\section{Conclusions}

This study selects water-cement ratio 0.5 and slump $16 \mathrm{~cm}$ for ACI mix design, and uses nano-clay to replace cement $0.1 \%, 0.3 \%$ and $0.5 \%$ by weight respectively. Cylinder specimens are made to test the effect of different high temperatures on the compressive strength and heat transfer coefficient, and the ignition loss of nano-clay cement paste is measured, concluded as follows:

1) For the specimen at the curing age of 28 days, $0.1 \%, 0.3 \%$ and $0.5 \%$ nano-clays replace cement by weight, the strength is reduced by $11.0 \%$ and increased by $5.9 \%$ and $3.3 \%$ respectively. The strength of specimens at other ages has similar trends and the $0.3 \%$ replacement increases the concrete strength significantly, the $1 \%$ nano-clay replacement reduces the concrete strength.

2) In $25^{\circ} \mathrm{C}$ and $300^{\circ} \mathrm{C}$ environments, the strength of normal concrete is increased by $13.4 \%$ and $9.5 \%$ respectively compared with control group. However, in $440^{\circ} \mathrm{C}, 500^{\circ} \mathrm{C}, 580^{\circ} \mathrm{C}, 800^{\circ} \mathrm{C}$ and $1000^{\circ} \mathrm{C}$ environments, the strength is reduced by $14.2 \%, 26.7 \%, 46.9 \%, 76.3 \%$ and $93.8 \%$ respectively. In different hot environments, the $0.1 \%$ nano-clay replacement can reduce the concrete strength, the $3 \%-5 \%$ replacement can increase the concrete strength, and the $0.3 \%$ replacement increases the concrete strength significantly.

3) For $0.1 \%$ - $0.5 \%$ nano-clay concrete, when the temperature is $300^{\circ} \mathrm{C}$ to $580^{\circ} \mathrm{C}$, the paste ignition loss decreasing amplitude is increased markedly.

4) The heat transfer coefficient of concrete decreases as the ambient temperature increases, the maximum decreasing amplitude occurs at $200^{\circ} \mathrm{C}-300^{\circ} \mathrm{C}$. The $0.3 \%$ and $0.5 \%$ nano-clay replacement can increase the heat transfer coefficient of concrete.

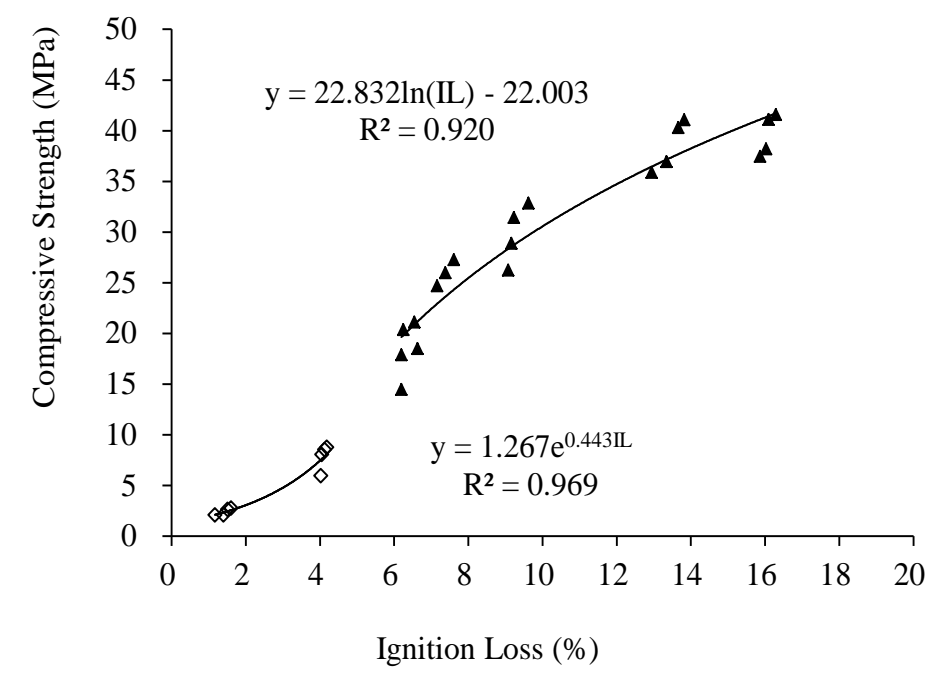

Figure 6. Relationship between ignition loss and compressive strength of nano-clay cement paste. 
5) When the nano-clay replaces $0 \%-0.5 \%$ of cement, and the ignition loss is lower than $6 \%$, the ignition loss is approximately in exponential relationship to the compressive strength. When the ignition loss is higher than $6 \%$, the ignition loss is approximately in logarithmic relationship to the compressive strength.

\section{References}

[1] Hung, T.-H. (2002) Change the World of Nanotechnology. Yingzhou Publishing House. (In Chinese)

[2] Chang, L.-T. (2002) Nano Materials. Wunan Publishing House. (In Chinese)

[3] Alelah, A.M. (1994) Synthesis of Organophilic Polymer-Clay Nanocomposites. Journal of Applied Polymer Science: Applied Polymer Symposium, 55, 153-172.

[4] Lin, I.-F. (2004) Discussion of the Fire Resistance of Mixed Radius Lightweight Concrete Block. Master Thesis, National Chung Hsing University. (In Chinese)

[5] Chen, K.-H. (2004) Discussion of the Fire Resistance of No Fine Aggregate Lightweight Concrete Block. Master Thesis, National Chung Hsing University. (In Chinese)

[6] Chen, S.-T. (1999) Assessment Method of fire Damage and Disaster Safety of Building. Scientific and Technical Publishing Co., Ltd. (In Chinese)

[7] Lin, T.D., Ellingwood, B. and Piet, O. (1987) Flexural and Shear Behavior of Reinforced Concrete Beams during Fires Tests. Portland Cement Association Research and Development Bulletin RD 091T.

[8] Neville, A.M. (1986) Properties of Concrete. London.

\section{Submit or recommend next manuscript to SCIRP and we will provide best service for you:}

Accepting pre-submission inquiries through Email, Facebook, LinkedIn, Twitter, etc.

A wide selection of journals (inclusive of 9 subjects, more than 200 journals)

Providing 24-hour high-quality service

User-friendly online submission system

Fair and swift peer-review system

Efficient typesetting and proofreading procedure

Display of the result of downloads and visits, as well as the number of cited articles

Maximum dissemination of your research work

Submit your manuscript at: http://papersubmission.scirp.org/ 